\title{
Boarding School that provide community-based mental health services
}

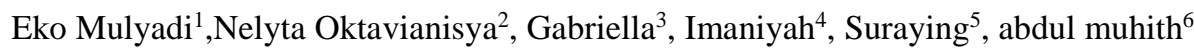 \\ \{eko.mulyadi@wiraraja.ac.id1, Gabriela.gaby77@yahoo.co.id ${ }^{3}$,imaniyahskep@gmail.com ${ }^{4}$, \\ abdulmuhith@unusa.ac.id $\left.{ }^{6}\right\}$
}

School of Nursing, Wiraraja University, Madura ${ }^{1}$, School of Nursing, Wiraraja University, Madura ${ }^{2}$, School of Nursing, Wiraraja University, Madura ${ }^{3}$, School of Nursing, Wiraraja University, Madura ${ }^{4}$, school of nursing, Madura polytechnic, Madura ${ }^{5}$, Nursing Department, University of Nahdlatul Ulama Surabaya ${ }^{6}$

\begin{abstract}
The aim of this study to describe a phenomena of Islamic boarding school that threat mental disorder patients. this study uses a phenomenological approach with 10 respondents consisting of caregivers, kyai (the leader of Islamic boarding school), and santri (student) with mental disorders. the results of the study show that boarding school not only accept ordinary santri, but also also accepts santri with mental disorders, interventions used to threat santri mental disorders with a spiritual approach, reflexology massage, occupational activity, environment therapeutic, and therapeutic communication, they do not distinguish ordinary santri with mental disorders except special interventions for the healing process, even santri who have recovered mental illness recruited work on that Islamic boarding school. This Islamic boarding school has seems applied the right principles threated mental disorder patients, but the good documentation will make it better.
\end{abstract}

Keyword: boarding school, community-based, mental health

\section{Introduction}

Patients with mental disorders in rural are difficult to get health services, while the number of mental disorders in the village and in the city is equal, health service disparities occur in mental health services, such as the separation of mental health services from other medical services, stigma associated with mental disorders and side effects of psychotropic drug use increasing disparity in mental health service [1].

mental disorders in Indonesia are increasing, the prevalence of severe mental disorders in the Indonesian population is 1.7 per mile, while the prevalence of mental emotional disorders with symptoms of depression and anxiety at 15 years of age reaches 14 million people. This figure is equivalent to 6 percent of Indonesia's population. Meanwhile, the prevalence of severe mental disorders such as schizophrenia in Indonesia reaches 400 thousand, and about 23 million people in worldwide [2].

Mental disorders are responsible for about $12-15 \%$ of the world's total disability - more than cardiovascular diseases, and twice as much as cancer. Their impact on daily life is even more extensive, accounting for more than 30\% of all years lived with disability (WHO.2003) 
Indonesia is a medium resources country . Medium-resource countries should also seek to provide related components such as outpatient clinics, community mental health care teams, acute inpatient care, long-term community-based residential care and occupational care [3].

With the existence of community-based mental health services can help overcome these problems by pfoviding long-term community-based residential care and occupational care. This services still maintain tradition and combine with modern, close to the community also raises local wisdom, hopefully can be accepted by the community.

\section{Methods}

This study uses a phenomenological approach, with in-depth interviews and direct observation. Participants in this study were 1 kyai (leader), 1 caregiver, and 4 santri (student) and 4 santri with mental disorders. All participants agreed to be the subject of this study, they were contacted by research assistance for take apart in the in-depth interview, participants were selected who knew the most about the boarding school, the results of the interviews were recorded and transcribed All participants were given informed consent and this study passed the ethical clearance of the wiraraja University of Health Faculty of Health Sciences. Data collection used in-depth interviews to get their experience in caring for students with mental disorders, interviews were conducted in direct research sites followed by direct observation in the field, the main questions in this in-depth interview were as follows (a) explain the history of the establishment of this boarding school, (b) what is the most unique thing in this boarding school, (c) what strategies are carried out to teach santri with mental disorders.

The interview then continued with further questions so that phenomena were discovered. Direct observation is done by looking directly at the place, starting from offices, mosques, lodges, to the environment around the Islamic boarding school

The thematic analysis process was used in this study, the interview data was then made a transcript, then read repeatedly and given a code, after being coded the researcher grouped the data according to the same idea, then from the ideas collected were themes. After the theme is made the next step is to define and name each foreign theme. All researchers gathered to discuss the results of the theme. The last process is to make an argument from the relationship from the research question.

To obtain the results of careful studies, this research attention to credibility, transferability and dependability, to obtain the data that is credible then the researchers did coding the data independently, and then discuss to get a deal on a theme. The process of data triangulation is also done to ensure valid data, the results of interviews compared with the results of field observations and theories or existing journals. Transferability is maintained by presenting data clearly and simply, so readers can know the similarities and differences between research and in clinical practice settings. Dependability is maintained by presenting sufficient data that describes the method of data collection to data analysis

\section{Result}

\subsection{History of the albajigur boarding school}

Al-Bajigur boarding school is located in the village of Tenonan, Manding, Sumenep, indonesia. was founded in 1996 by KH Abdurrahman who had the courage enter the village, 
which at that time were many criminals. the establishment of the Al Bajigur Islamic Boarding School, the criminal slowly began to repent, even some became santri (student) in that boarding school. That is why named Al-Bajigur (bajingan nganggur) which means the retired criminal.

\subsection{Receiving santri with mental disorders}

Not only accepting normal santri, this boarding school also accepts mental disorder santri, in the 2018 number of normal santri is 93 (45 man and 48 woman ), while mental disorder santri are 23, during interviews we find 9 santri with mental disorder because some had recovered and returned to their homes. These students do not only come from local areas even from abroad such as Brunei Darussalam. The problems behind them are very diverse, ranging from family issues, romance, economy, and drug addictions. Santri who have been recovered are allowed to return to their home

\subsection{Spiritual activities}

Spiritual Activities carried out by santri with mental disorders are reciting qur'an, prayer togather, dhikr and burdah (Islamic spiritual activity) around the boarding school, listening to religious lectures, and so forth. There is no distinction between normal santri and mental disorder students, except for students who are not cooperative, such as those who are still violent and cannot interact.

\subsection{Occupational care}

Santri with mental disorders are given an occupational activity, such as cleaning the area around the boarding school, gardening, cutting wood, these activities are carried out every day with the aim of providing activities to the santri and interacting with the environment to accelerate the healing process.

\subsection{Reflexology}

Students with mental disorders were also given reflexology, which was carried out by the boarding school caregivers, caregivers explained the purpose of reflexology to enhance blood circulation to the brain.

\subsection{Water therapy}

Santri with mental disorders were bathed on certain days, especially Friday night, the santri were given coconut water and bathed with cold water mixed with coconut water while praying for his recovery. Then the normal santri are encouraged to carry out burdah for the santri who have this mental disorder.

\subsection{Therapeutic communication}

Kyai and caregivers treat santri with mental disorders as well as other santri, their goal is to increase the self-esteem of students with mental disorders, even they are called santri as a substitute term for patients, they prefer to be called santri rather than patients.

\subsection{Therapeutic environment}

The location of Islamic boarding schools is located in the hills and is quite enough, far from urban areas, and the natural sound as sound of birds, wind and many trees support a therapeutic environment that supports the healing process

\section{Discussion}

From the blood data of PRC type, a mathematical function was obtained for the blood supply of PRC types using Mathematica software. When one family member gets ill with a mental disorder, traditional healing sites are the places which are tried first. Having tried and failed all other alternatives, modern mental health care centers are very often the last places where help is sought (Alem,2002). this often happens in rural communities in Indonesia. 
there is increasing evidence that disparities in healthcare provision contribute to poor physical health outcomes. These inequalities have been attributed to a combination of factors including systemic issues, such as the separation of mental health services from other medical services, healthcare provider issues including the pervasive stigma associated with mental illness, and consequences of mental illness and side effects of its treatment [1]. Mediumresource countries should also seek to provide related components such as outpatient clinics, community mental health care teams, acute inpatient care, long-term community-based residential care and occupational care.

Spirituality is experienced through daily lived experience, and cultures may influence the spiritual well-being perceived by individuals, Higher levels of depressive symptoms were associated with power spiritual well-being, and a higher level of spiritual well-being was positively related to higher level of health-related quality of life [4]. the learning process at this Islamic boarding school lasts 24 hours, for students with mental disorders stressed on discipline and orientation of prayer times, this activity provides a spiritual and cultural experience, that it is expected to reduce depression. Reciting and learning qur'an also provided in this spiritual activity of santri, its also known that qur'ani therapy has implications for cognitive, affective, and motoric health.

Occupational therapy interventions have the potential to improve functioning and mental health outcomes for people with anxiety [5]. It can help people with Serius MentaI illness improve and maintain performance and participation in employment and education, occupational therapy is a vital part of the holistic approach to rehabilitation. In the community setting, facilities for clients with mental disorder are far from adequate throughout the world, but areal attempt to accommodate them in their home context is being made. Primary healthcare clinics are administering chronic medicines from the clinics and to the home base. Mental disorder clients are followed up on a regular basis; however, some clients do slip through the system. Support groups can be an effective medium to normalize their behavior within the community context [6]. Cultural sensitivity is a crucial component of health care. Particularly in psychiatric settings As society becomes more multicultural, it is essential for occupational therapists to continue to develop cultural competence $[7,8]$.

Reflexology is a popular form of complementary and alternative medicine (CAM) Although some studies show negative results [9], present research show that Reflexology is an effective medical intervention in reducing depression in patients undergoing hemodialysis [10] Reflexology was found to reduce the symptoms experienced by breast cancer patients, while at the same time increasing the functional and general health status [11]. it has been found that foot reflexology in Over Activity Bladder treatment increases quality of life, and decreases depressive symptoms. reflexology not only reduces anxiety, but also reduces pain intensity [12].

The use of water for various treatments (hydrotherapy) is probably as old as mankind. Hydrotherapy is one of the basic methods of treatment widely used in the system of natural medicine (Mooventhan \& Nivethitha, 2014) Many studies/reviews reported the effects of hydrotherapy only on very few systems and there is lack of studies/reviews in reporting the evidence based effects of hydrotherapy on various systems. Cold water treatments works well in the treatment of depression and improves the recovery time. By cold-water therapy treats depression patients by immersing the body in water, applying a whole-body wrap, and administering a cold shower that lowers brain temperature to improve symptoms of depression.

Studies show that cold water exposure to different parts of the body for different time intervals have drastic effects on body and majorly contributes towards active brain function. One hour full body water immersion (WI) at different temperatures showed different effects. At $32 \mathrm{C}$, it lowered heart rate by $15 \%$, systolic blood pressure by $11 \%$ and diastolic blood pressure 
by $12 \%$. In addition, cold water therapy is the example of stress induced analgesia and is expected to "crowd out" or suppress psychosis related neurotransmission within mesolimbic system.

Communication can be seen as the main ingredient in medical care, especially in mental health. The purposes of communication are to creating a good inter-personal relationship, exchanging information and making treatment-related decisions and most therapeutic modalities rely on therapeutic communication, mental health nurses and caregiver should develop therapeutic interpersonal relations.

A good environment can improve the healing process, the sounds of nature such as birds, the sound of the wind and beautiful scenery can make thoughts and feelings calm, the environment in this boarding school meets these criteria, so it is very possible to help the healing process of students with mental disorders

\section{Conclusion}

This boarding school has helped overcome mental disorders by providing community based mental health services, and seems to have implemented appropriate interventions, Future suggestions for improving service are by improving documentation.

\section{Reference}

[1] Lawrence, D., \& Kisely, S. (2010). Review: Inequalities in healthcare provision for people with severe mental illness. Journal of Psychopharmacology, 24(4_suppl), 61-68. https://doi.org/10.1177/1359786810382058

[2] Muhith, A. (2015). Pendidikan Keperawatan Jiwa (Teori dan Aplikasi). Yogyakarta: Andi

[3] Muhith, A., dkk (2014). Kondisi Ekonomi Dan Budaya Keluarga Dengan Status Gizi Balita. Jurnal Ners Vol.9 No.1. Fakultas Keperawatan Universiatas Airlangga Surabaya.

[4] Lee, Y.-H., \& Salman, A. (2018). The Mediating Effect of Spiritual Well-being on Depressive Symptoms and Health-related Quality of Life Among Elders. Archives of Psychiatric Nursing, 32(3), 418-424. https://doi.org/10.1016/j.apnu.2017.12.008

[5] Helfrich, C. A., Peters, C. Y., \& Chan, D. V. (2010). Trauma symptoms of individuals with mental illness at risk for homelessness participating in a life skills intervention. Occupational Therapy International, n/a-n/a. https://doi.org/10.1002/oti.308

[6] Crouch, R., \& Vivyan Alers. (2014). Occupational Therapy in Psychiatry and Mental Health (Fifth edition.). John Wiley \& Sons ltd.

[7] Dillard, M., Andonian, L., Flores, O., Lai, L., MacRae, A., \& Shakir, M. (1992). Culturally Competent Occupational Therapy in a Diversely Populated Mental Health Setting. American Journal of Occupational Therapy, 46(8), 721-726. https://doi.org/10.5014/ajot.46.8.721

[8] Muhith A., dkk (2018). The spatial patten and risk factors of leprosy occurence in barru indonesia. Medicine: Public health, Evironmental and Occupational Health. Indian Journal of Public health Research \& Development. Volume. 9 Number 8. First page 
1489-1494. (08 Agustus 2018), ISSN 0978-0245 (print), ISSN 0976-5506 (Electronic). DOI Number: 10.5958/0976-5506.2018,00943.9.

[9] Ernst, E., Posadzki, P., \& Lee, M. S. (2011). Reflexology: An update of a systematic review of randomised clinical trials. Maturitas, 68(2), 116-120. https://doi.org/10.1016/j.maturitas.2010.10.011

[10] Amini, Z., Mostafa, R., Hamid Reza, B., Akram, S., Leila, J., \& Azadeh, K. (2017). The effects of foot reflexology on the level of depression in patients under hemodialysis. Journal of Nursing Education, 5(6), 33-39. https://doi.org/10.21859/jne-05065

[11] Özdelikara, A., \& Tan, M. (2017). The effect of reflexology on the quality of life with breast cancer patients. Complementary Therapies in Clinical Practice, 29, 122-129. https://doi.org/10.1016/j.ctcp.2017.09.004

[12] Aydin, Y., Aslan, E., \& Yalcin, O. (2016). Effect of Reflexology to Depressive Symptoms in Women With Overactive Bladder: Holistic Nursing Practice, 30(5), 294 300. https://doi.org/10.1097/HNP.0000000000000166 